\title{
FUNGSI KONSUMSI RUMAH TANGGA DI INDONESIA (PENDEKATAN MODEL KOREKSI KESALAHAN)
}

\author{
Maryam Sangaji \\ Fakultas Ekonomi Universitas Pattimura Ambon
}

\begin{abstract}
Keynesian theory about consumption states that household consumption (C) related positively with present income: the greater income the more consumption. Beside that, interest rate influence negatively toward household consumption, because if the interest rate is low then the loan cost also low, so the factor encourage household to increase it consumption. The results showed that income level related positively with household consumption level. While the interest rate related negatively with consumption level. It means that the greater income encourage the household to increase its consumption. But the increase is not as high as the income level. Then the higher interest rate will cause the household increase its saving, so decrease the consumption. The test by using error correction model (ECM) showed that balance variable of ECT is significant, where for that the household consumption adapted with the income level change and the interest rate at the same period.
\end{abstract}

Keywords: Household Consumption Level, Income, Interest Rate, and Error Correction Model.

\section{A. PENDAhUluan}

Dalam analisa makroekonomi, konsumsi rumah tangga sering mendapat perhatian khusus. Menjadi perhatian secara lebih mendalam karena beberapa alasan. Pertama, konsumsi rumah tangga memberikan sumbangan yang paling besar kepada pendapatan nasional. Di kebanyakan negara, pengeluaran konsumsi meliputi 60-70 persen dari pendapatan nasional. Berarti perbelanjaan ini adalah lebih penting dari gabungan ketiga perbelanjaan yang lain, yaitu investasi perusahaan, perbelanjaan pemerintah dan ekspor bersih (ekspor dikurangi impor). Kedua, konsumsi rumah tangga mempunyai pengaruh yang sangat penting dalam menentukan fluktuasi kegiatan ekonomi dari satu waktu ke waktu lainnya. Sementara itu, dalam jangka panjang, pola konsumsi dan tabungan masyarakat sangat besar pengaruhnya terhadap pertumbuhan ekonomi (Sukirno, 2000).

Mengingat konsumsi memiliki peranan yang sentral, mengetahui perilaku konsumsi, oleh karenanya, merupakan kebutuhan yang mendesak untuk bisa memahami jalannya perekonomian dari waktu ke waktu. Lebih dari itu rumusan kebijakan ekonomi makro harus selalu didasarkan pada pemahaman yang benar mengenai perilaku konsumsi. Hal ini demikian karena salah satu dampak akhir dari sebuah kebijakan makro ekonomi sangat ditentukan oleh besarnya angka pengganda, dan besarnya angka tersebut sangat tergantung dari perilaku konsumsi (yang tercermin pada besarnya hasrat konsumsi marjinal). Namun sayangnya, studi mengenai konsumsi masih sangat terbatas untuk kasus Indonesia. Padahal teori dan hasil-hasil penelitian di negara lain telah mengalami perkembangan yang sangat cepat (Krisnawati; et.all,2004. Ismail, et.all, 2005).

Peranan konsumsi menjadi semakin penting ketika krisis melanda perekonomian Indonesia. Sejak tahun 1997, sumbangan konsumsi terus mengalami kenaikan dan puncaknya terjadi pada tahun 1999 dimana sumbangannya mencapai 70\%. Peningkatan yang sangat tinggi tidak terlepas 
dari karakteristik perilaku konsumsi itu sendiri, dan fluktuasinya tidak seperti fluktuasi investasi atau eskpor bersih. Pada saat perekonomian mengalami depresi, yang ditandai oleh merosotnya GDP beserta komponennya, konsumsi memang mengalami penurunan tetapi penurunan tidak setajam penurunan dari komponen lain, sehingga sumbangannya terhadap GDP justru menjadi lebih tinggi dibanding sebelumnya. Karena memiliki peranan yang sangat dominan, maka kedudukan konsumsi sangat menentukan dalam pertumbuhan ekonomi. Gambaran ini tidak mengherankan kalau pada masa-masa pemulihan ekonomi pasca-krisis, konsumsi menjadi sumber utama pertumbuhan ekonomi Indonesia (Bank Indonesia, 2007).

Berdasarkan pemaparan diatas, dalam penelitian ini penulis mencoba mengkaji permasalahan menyangkut : Faktor Pendapatan dan Tingkat Bunga yang mempengaruhi Tingkat Konsumsi Rumah Tangga di Indonesia?

\section{B. KAJIAN TEORITIS}

\section{John Maynard Keynes dan Fungsi Konsumsi}

Keynes menunjukkan bahwa keputusan konsumen dalam konsumsi mempunyai implikasi yang sangat penting sebagai acuan dalam menentukan kebijakan ekonomi makro suatu negara. Melalui parameter marginal propensity to consume (MPC) akan diketahui besarnya koefisien multiplier yang pada gilirannya akan menentukan keseimbangan pendapatan nasional, kesempatan kerja, dan tingkat harga dari suatu perekonomian. Dengan mengetahui parameter di atas pemerintah dapat mengambil kebijakan fiskal maupun kebijakan moneter untuk mencapai target ekonomi makro (Burhan, 2005).

Teori Keynes menyatakan bahwa konsumsi sekarang tergantung pada pendapatan sekarang yang dalam bentuk fungsi konsumsi dirumuskan:

$\mathrm{C}_{\mathrm{t}}=\mathrm{C}_{0}+\mathrm{C}_{1} \mathrm{Y}_{\mathrm{t}}$

Dimana $\mathrm{C}_{\mathrm{t}}$ adalah konsumsi sekarang (current consumption), $\mathrm{Y}_{\mathrm{t}}$ pendapatan sekarang (current income), $\mathrm{C}_{0}$ konsumsi otonom (autonomous consumption), dan $\mathrm{C}_{1}$ adalah marginal propensity to consume (MPC). Fungsi konsumsi di atas dapat digambarkan pada gambar 1

Dari fungsi dan gambar di bawah dapat dilihat bahwa (a) MPC konstan dan selalu lebih kecil dari average propensity to consume (APC) dan (b) APC semakin turun dengan makin meningkatnya pendapatan. Selanjutnya Keynes menambahkan bahwa hubungan tersebut relatif stabil dan pendapatan nominal yang lebih tinggi akan berakibat makin besarnya proporsi untuk ditabung.

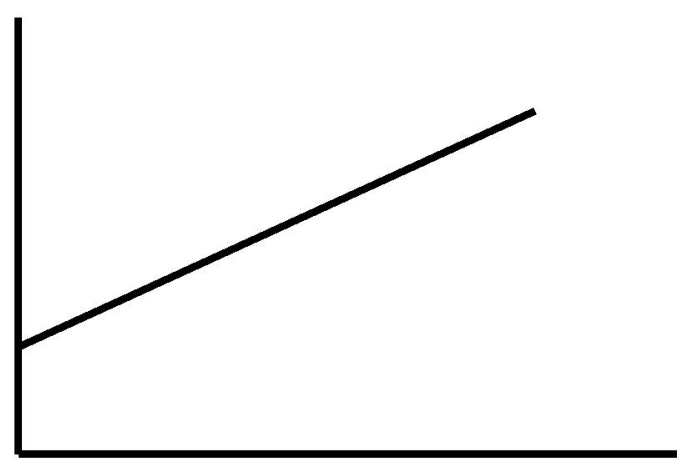

\section{Gambar 1: Hubungan Konsumsi dan Pendapatan}

Keynes menduga bahwa kecenderungan mengkonsumsi marjinal adalah antara nol dan satu, dimana kecenderungan mengkonsumsi rata-rata (average propensity to consume) turun ketika pendapatan naik, selain itu pendapatan sekarang adalah determinan konsumsi yang utama. Ketika 


\section{Journal of Indonesian Applied Economics Vol. 3 No. 2 Oktober 2009, 150-165}

terjadi kenaikan pada pendapatan tidak akan menaikkan konsumsi sebesar kenaikan pendapatan. Akan tetapi menurutnya tingkat bunga tidak memiliki peran penting. Ia menyatakan bahwa pengaruh tingkat bunga terhadap konsumsi hanya sebatas teori. Berdasarkan pada pengalamannya bahwa pengaruh jangka-pendek dari tingkat bunga terhadap pengeluaran individu dari pendapatannya bersifat sekunder dan relatif tidak penting (Mankiw, 2003).

\section{Teori Konsumsi dengan Hipotesis Siklus Hidup (Life Cycle Hypothesis)}

Teori "hipotesis siklus hidup" berasumsi bahwa orang menabung untuk memuluskan konsumsi mereka selama hidup. Satu tujuan pentingnya adalah untuk mendapat pendapatan masa pensiun yang mencukupi. Oleh karena itu, orang bekerja dan cenderung menabung sehingga dapat menambah simpanan untuk pensiun dan kemudian membelanjakan tabungan mereka yang terkumpul pada masa tua (Samuelson dan Nordhaus, 2004). Menurut teori ini terdapat tiga bagian yang mempengaruhi faktor sosial ekonomi seseorang terhadap pola konsumsi. Pertama, seseorang berumur nol tahun, seseorang tersebut tidak menghasilkan pendapatan sendiri (mengkonsumsi tetapi tidak menghasilkan pendapatan). Kedua dimana seseorang berusia kerja (dapat menghasilkan pendapatan sendiri) sehingga ia tetap berada pada usia tidak bekerja lagi, pada keadaan ini ia mengalami dissering. Ketiga ketika seseorang berusia tua dimana orang tersebut tidak mampu lagi menghasilkan pendapatan sendiri pada keadaan ini ia dissering.

Metwally (1995) berpendapat sesuai dengan hipotesis siklus / daur hidup, konsumsi tidak saja bergantung pada pendapatan rumah tangga pada saat ini, tapi juga pada kekayaan dan pendapatan yang diharapkan di masa mendatang. Konsumen akan mendistribusikan sumber daya yang ada untuk mengatur konsumsi selama hidupnya, karena itu konsumsi harus dihubungkan dengan kehidupan individu dan tidak untuk satu periode saja. Jika konsumsi seseorang selama periode 1 ...... t; maka fungsi daya guna selama hidupnya bergantung pada konsumsi keseluruhan dalam satu periode atau:

$$
\mathrm{U}=\mathrm{U}\left(\mathrm{C}_{1}, \mathrm{C}_{2}, \ldots \ldots \ldots \ldots . . \mathrm{C}_{\mathrm{t}}\right)
$$

Dalam fungsi konsumsi yang cocok adalah dalam bentuk:

$$
\mathrm{C}_{\mathrm{t}}=\mathrm{aW}_{\mathrm{t}-1}+\mathrm{bY}_{\mathrm{t}}+\mathrm{cY}_{\mathrm{t}}^{\mathrm{e}}
$$

Di mana: W sebagai jumlah kekayaan, dan $\mathrm{Y}^{\mathrm{e}}$ sebagai nilai sekarang pendapatan yang akan datang. Pendukung hipotesis ini menganjurkan untuk menggunakan pendapatan sekarang sebagai pengganti $Y^{\mathrm{e}}$, dan karena itu fungsi konsumsi menjadi:

$$
\mathrm{C}_{\mathrm{t}}=\mathrm{a}_{1} \mathrm{~W}_{\mathrm{t}-1}+\mathrm{a}_{2} \mathrm{Y}_{\mathrm{t}}
$$

Hipotesis ini, menunjukkan bahwa redistribusi pendapatan menguntungkan kelompok miskin dan kelompok yang memerlukan, namun tidak berpengaruh besar pada pengeluaran konsumsi agregat.

Dari gambar 2 dapat dilihat bahwa konsumsi pada waktu t tidak mengikuti besarnya pendapatan pada waktu t sebagaimana teori Keynes, tetapi mengikuti pola pendapatan jangka panjang yang dirumuskan sebagai tunai pendapatan pada waktu t. Implikasinya, APC dalam siklus hidup berbeda satu sama lain di mana pada masa awal kehidupan dan masa tua APC tinggi sedang pada siklus usia produktif APC rendah atau dengan perkataan lain APC berbanding terbalik dengan besarnya pendapatan.

\section{Teori Konsumsi dengan Hipotesis Pendapatan Relatif (Relative Income Hypothesis)}

Menurut Duesenberry dalam teori hipotesis pendapatan relatifnya (relative income hyphothesis) menyatakan bahwa selalu ada kecenderungan setiap anggota masyarakat untuk meningkatkan konsumsi mereka begitu terjadi peningkatan pendapatannya. Fluktuasi tingkat pendapatan menyebabkan perilaku konsumen (rumah tangga) akan berbeda dalam jangka pendek dan jangka panjang. Hal ini terjadi karena secara esensial mereka tidak begitu memperhatikan tingkat konsumsi absolut mereka, sebagaimana konsumsi relatifnya terhadap anggota masyarakat sekitar lingkungannya. Apabila konsumen senantiasa melihat pola konsumsi rumah tangga tetangganya 


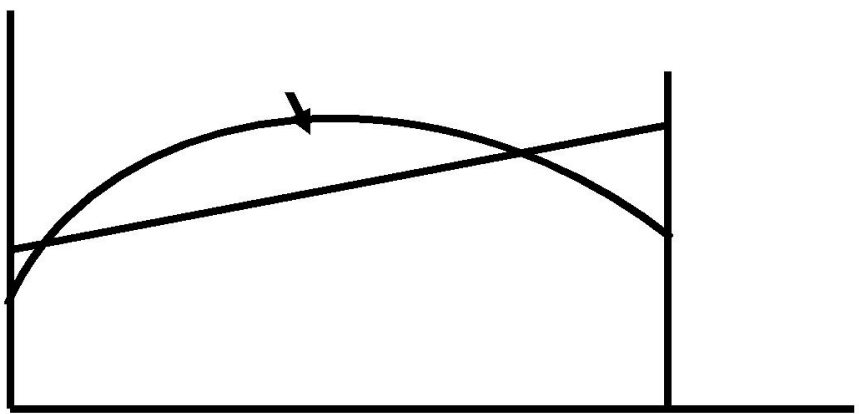

Gambar 2. Pola Konsumsi Menurut Hiptesis Daur Hidup

yang lebih kaya, maka ada efek demonstrasi (demonstration effect), tetapi peniruan pola konsumsi tetangga tersebut pada masyarakat sekelilingnya.

Teori konsumsi dengan menggunakan hipotesis pendapatan relatif dikemukakan oleh James Duesenberry dengan pendekatan dua asumsi yang digunakan:

1. Selera rumah tangga atas barang konsumsi adalah independent yaitu terpengaruh atas pengeluaran yang dilakukan tetangga.

2. Pengeluaran konsumsi adalah irrevisible. Artinya pola pengeluaran pada saat penghasilan naik berbeda dengan pada saat penghasilan mengalami penurunan.

Kemudian faktor lain yang dapat mempengaruhi pengeluaran konsumsi masyarakat adalah pengeluaran konsumsi yang dilakukan oleh masyarakat lingkungannya, apabila seseorang tinggal di lingkungan masyarakat yang mempunyai konsumsi yang tinggi maka orang tersebut cenderung mengikuti pola konsumsi masyarakat dengan pola konsumsi yang tinggi pula. Orang selalu mencapai standar konsumsi pada tingkat pendapatan tertinggi yang pernah dicapai. Jika pendapatan relatifnya sekarang menurun, seseorang tidak segera akan mengorbankan standar konsumsi yang telah dicapai. Jadi, di sini ada pengaruh searah (rachet effect), yaitu konsumen menyesuaikan sedikit konsumsinya akibat penurunan pendapatan sekarang. Tetapi penyesuaian tersebut tidak simetri karena meningkatnya pendapatan relative, mereka segera akan meningkatkan konsumsi ke tingkat tertinggi yang pernah dicapai. Karena itulah, menurut hipotesis ini, konsumsi rata-rata dan konsumsi marginal adalah konstan. Keduanya tetap sama meskipun pendapatan naik ke tingkat pendapatan puncak. Jika pendapatan sekarang lebih kecil dari pendapatan puncak, maka hasrat konsumsi marginal akan lebih kecil dari hasrat konsumsi rata-rata. Akan tetapi hasrat konsumsi rata-rata akan meningkat jika pendapatan sekarang meningkat.

\section{Teori Konsumsi dengan Hipotesis Pendapatan Permanen (Permanent Income Hypothesis)}

Pada tahun 1957, Milton Friedman dalam bukunya menjelaskan hipotesis pendapatan-permanen (permanent income hypothesis) menggambarkan perilaku konsumen. Hipotesis pendapatanpermanen Friedman melengkapi hipotesis daur hidup Modigliani: keduanya menggunakan teori konsumsi Irving Fisher untuk menyatakan bahwa konsumsi seharusnya tidak hanya bergantung pada pendapatan sekarang. Namun tidak seperti hipotesis daur-hidup, yang menekankan bahwa pendapatan mengikuti pola reguler selama masa hidup seseorang. Hipotesis pendapatan-permanen menekankan bahwa manusia mengalami perubahan acak dan temporer dalam pendapatan mereka dari tahun ke tahun (Mankiw, 2003).

Menurut teori ini pendapatan masyarakat dibagi menjadi dua bagian, yaitu pendapatan permanen (permanent income), adalah merupakan pendapatan yang selalu diterima pada setiap periode tertentu dan pendapatan sementara (transitory income) adalah tambahan atau pengurangan pendapatan yang tidak diperkirakan atau diharapkan (Dornbusch \& Fisher, 1987). Hipotesis pendapatan- 


\section{Journal of Indonesian Applied Economics Vol. 3 No. 2 Oktober 2009, 150-165}

permanen menekankan bahwa manusia mengalami perubahan acak dan temporer dalam pendapatan mereka dari tahun ke tahun. Teori Friedman ini, seperti hipotesis siklus kehidupan, juga berpendapat bahwa konsumsi rumah tangga terutama ditentukan oleh pendapatan jangka panjang. Ia mendefenisikan pendapatan permanen sebagai pendapatan jangka panjang rata-rata yang diharapkan akan diterima dari "human and nonhuman wealth". Yang dimaksudkan dengan pendapatan dari human wealth adalah pendapatan yang diterima dari menyediakan kemahiran manusia dan sebagai ganjarannya mereka akan memperoleh gaji, upah dan remunerasi lain dari bekerja. Sedangkan pendapatan dari non-human wealth meliputi pendapatan yang diperoleh dari harta kekayaan dan harta tetap seperti pendapatan dari pemilikan saham, obligasi dan real estate.

Jika hipotesis pendapatan permanen benar dan konsumen memiliki ekspektasi rasional maka perubahan konsumsi mungkin akan tak terduga dan perubahan ini dikenal sebagai random walk. Alasan yang diberikan sebagai berikut: jika hipotesa ini benar maka fluktuasi pendapatan akan diikuti oleh konsumen dengan mencoba untuk mengurangi fluktuasi konsumsinya. Tetapi dengan adanya ekspektasi terhadap tingkat pendapatan akan mengubah tingkat konsumsi. Misalkan seseorang memperoleh kenaikan pangkat maka akan menaikkan konsumsinya, demikian sebaliknya. Jadi jika konsumen mempergunakan sepenuhnya informasi maka tingkat konsumsinya tidak dapat diprediksi dengan baik. Inilah yang dinamakan random walk. Pada kenyataannya random walk teori tidak sepenuhnya ada dalam dunia nyata, tetapi banyak ekonom yakin asumsi ekspektasi rasional ini merupakan pendugaan yang cukup baik terhadap realita.

Menurut Friedman, dalam jangka panjang konsumen telah menentukan proporsi konsumsi permanen terhadap pendapatan permanennya, misalnya $\mathrm{k}=\mathrm{C}_{\mathrm{p}} / \mathrm{Y}_{\mathrm{p}}$ seperti yang ditunjukkan oleh raric 1 nada ramhar 2

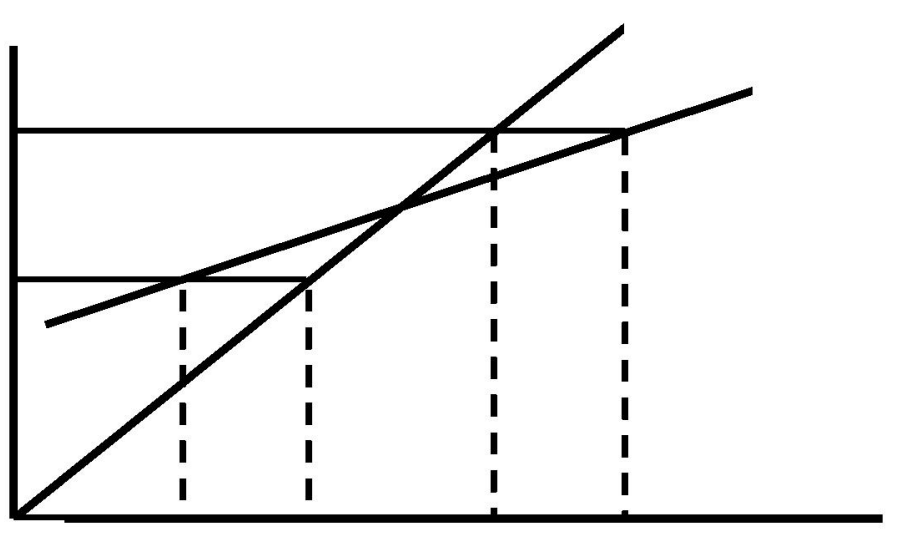

\section{Gambar 3: Fungsi Konsumsi menurut Hipotesis Pendapatan Permanen}

Pada masa boom, pendapatan sebenarnya (observed income), $\mathrm{Y}_{0-2}$, lebih besar dari pendapatan permanen, $\mathrm{Y}_{\mathrm{p}-2}$, atau pendapatan sementara $>0$, sedangkan konsumsi sebenarnya (observed consumption) sama dengan konsumsi permanen sehingga APC $<\mathrm{k}$, sementara pada masa krisis pendapatan sebenarnya (observed income), $\mathrm{Y}_{0-1}$, lebih kecil dari pendapatan permanen, $\mathrm{Y}_{\mathrm{p}-1}$, atau pendapatan sementara $<0$, sedangkan konsumsi sebenarnya (observed consumption) sama dengan konsumsi permanen sehingga APC $>$ k. Dengan demikian dalam jangka pendek sepanjang siklus ekonomi, APC tidak konstan, tetapi relatif kecil pada saat pendapatan tinggi dan relatifbesar pada saat pendapatan rendah.

Friedman juga menjelaskan bahwa faktor kunci yang menentukan slope dari fungsi konsumsi ialah variasi relatif dari pendapatan permanen dan pendapatan sementara. Peningkatan pendapatan sekarang akan mempengaruhi konsumsi dan hanya terjadi jika peningkatan pendapatan tersebut merefleksikan peningkatan pendapatan permanen. Ketika variasi pendapatan permanen jauh lebih besar dari variasi pendapatan sementara, maka hampir semua variasi pendapatan sekarang adalah 
refleksi dari variasi pendapatan permanen sehingga konsumsi akan naik turun hampir proporsional dengan pendapatan sekarang. Tetapi jika variasi pendapatan permanen jauh lebih kecil dari variasi pendapatan permanen sehingga konsumsi akan bereaksi sedikit saja terhadap pendapatan sekarang.

Perbedaan pendapatan rumah tangga mencerminkan perbedaan dalam pekerjaan dan perbedaan usia dalam daur hidup rumah tangga tersebut. Atau dengan kata lain, pada data cross section variasi pendapatan sementara jauh lebih besar dari variasi pendapatan permanen. Akibatnya, koefisien fungsi konsumsi (MPC) lebih kecil dari satu secara signifikan dan intercept positif. Pada data time series, variasi pendapatan permanen lebih besar dari variasi pendapatan sementara sehingga estimasi fungsi konsumsi akan menghasilkan koefisien mendekati satu dan interceptnya mendekati nol (Romer, 1996).

\section{METODE PENELITIAN DAN ANALISIS DATA}

\section{Data dan Sumbernya}

Penelitian ini berkaitan dengan pengukuran hubungan variabel ekonomi makro yang mendasarkan pada suatu teori ekonomi. Selanjutnya dijabarkan dalam model ekonometri. Dari model ekonometri tersebut dengan dukungan data dan kemudian diolah dengan metode statistik untuk memperoleh nilai parameter hubungan ekonomi dari variabel ekonomi tersebut. Data yang digunakan dalam penelitian ini merupakan data sekunder yang sifatnya runtun waktu (time series). Data diambil dari instansi yang terkait dengan permasalahan penelitian, antara lain Laporan Bank Indonesia (SEKI), Biro Pusat Statistik (BPS), serta sumber-sumber lainnya. Data yang dikumpulkan antara lain meliputi data pengeluaran konsumsi rumah tangga, pendapatan, suku bunga selama periode tahun $2000.1-2006.4$.

\section{Model Analisis}

Untuk menguji permasalahan terkait faktor pendapatan dan tingkat suku bunga yang mempengaruhi tingkat konsumsi rumah tangga, digunakan model persamaan regresi linier berganda sebagai berikut (Gujarati, 1995):

$$
\begin{aligned}
& \mathrm{C}=\beta \mathrm{o}+\beta_{1} \text { Income }+\beta_{2} \mathrm{r}+\varepsilon \mathrm{i} \\
& \begin{array}{ll}
\text { Dimana: } & \\
\mathrm{C} & =\text { Tingkat konsumsi rumah tangga } \\
\text { Income } & =\text { Pendapatan Nasional } \\
\mathrm{R} & =\text { Suku Bunga }
\end{array}
\end{aligned}
$$

\section{Uji Stasioneritas Data (Unit root test)}

Ada beberapa metode uji stasionaritas dengan menggunakan uji akar-akar unit. Uji akar unit yang dikembangkan oleh Dickey-Fuller merupakan uji yang banyak diaplikasikan. Uji tersebut disebut uji DF (Dickey-Fuller) dan uji ADF (Augmented Dickey-Fuller). Adapun formulasi uji DF dan ADF sebagai berikut:

$$
\begin{array}{cl}
D X_{t}=a_{0} & +a_{1} B X_{t}+\sum_{t=1}^{k} a_{2} B^{i} D X_{t} \\
D X_{t}= & b_{0} \\
\text { dimana: } & b_{1} B X_{t}+\sum_{t=1}^{k} b_{2} B^{i} D X_{t} \\
\mathrm{X} & =\text { variabel yang diamati } \\
\mathrm{B} & =\text { lag operator } \\
\mathrm{DX} & =\mathrm{X}_{\mathrm{t}}-\mathrm{X}_{\mathrm{t}-1} \\
\mathrm{BX}_{\mathrm{t}} & =\mathrm{X}_{\mathrm{t}-1} \\
\mathrm{t} & =\text { trend waktu }
\end{array}
$$




\section{Journal of Indonesian Applied Economics Vol. 3 No. 2 Oktober 2009, 150-165}

\section{Model Koreksi Kesalahan (Error Correction Model)}

Teknik untuk mengoreksi ketidakseimbangan jangka pendek menuju pada keseimbangan jangka panjang disebut Error Correction Mechanism (ECM), yang dikenalkan oleh Sargan dan dipopulerkan oleh Engle dan Granger (Nachrowi dan Usman, 2006). Model ECM untuk melihat hubungan tingkat konsumsi rumah tangga dengan tingkat pendapatan dan suku bunga adalah sebagai berikut:

$\Delta \mathrm{C}=\alpha_{0}+\alpha_{1} \Delta$ Income $+\alpha_{2} \Delta \mathrm{r}+\alpha_{3} \mathrm{ECT}_{\mathrm{t}-1}+\mathrm{e}_{\mathrm{t}}$

$\mathrm{ECT}_{\mathrm{t}-1}$ adalah error kointegrasi lag 1, atau secara matematis dituliskan:

$\mathrm{ECT}_{\mathrm{t}-1}=\mathrm{C}_{\mathrm{t}-1}-\beta_{0}-$ Income $_{\mathrm{t}-1}+\mathrm{r}_{\mathrm{t}-1}$

Model di atas terlihat bahwa hubungan perubahan pendapatan dan suku bunga terhadap tingkat konsumsi rumah tangga dalam jangka panjang akan diseimbangkan oleh error sebelumnya. Dalam persamaan di atas, $\Delta \mathrm{r}, \Delta$ Income menggambarkan gangguan jangka pendek dari Income, $r$, dan error kointegrasi merupakan penyesuaian menuju keseimbangan jangka panjang. Dengan demikian, jika koefisien $\alpha_{3}$ signifikan, maka koefisien tersebut akan menjadi penyesuaian bila fluktuasi variabel-variabel yang diamati menyimpang dari hubungan jangka panjangnya.

Bila $\mathrm{ECT}_{\mathrm{t}-1}>0$, maka modelnya tidak dalam keseimbangan. Oleh karena itu nilai $\alpha_{4}$ diharapkan negatif. Dengan demikian, $\alpha_{3} \mathrm{ECT}_{\mathrm{t}-1}<0$ dan akibatnya $\Delta \mathrm{C}<0$ agar kembali pada keseimbangan. Sebaliknya bila $\mathrm{ECT}_{\mathrm{t}-1}>0$ maka C berada di bawah nilai keseimbangannya, dan $\alpha_{3} \mathrm{ECT}_{\mathrm{t}-1}>0$ yang mengakibatkan $\Delta \mathrm{C}>0$, sehingga nilai $\mathrm{C}$ meningkat pada periode ke-t. Dengan demikian, nilai absolut dari $\alpha_{3}$ menentukan seberapa cepat keseimbangan bisa tercapai kembali bila terdapat penyimpangan.

\section{Hasil Analisis Data}

\section{Uji Stasioneritas Data (Unit root test)}

Regresi yang menggunakan data time series yang tidak stasioner kemungkinan besar menghasilkan regresi lancung (spurious regression). Regresi lancung terjadi jika koefisien determinasi cukup tinggi tapi hubungan antara variabel independen dan variabel dependen tidak mempunyai makna. Hal ini terjadi karena hubungan keduanya yang merupakan data time series hanya menunjukkan trend saja. Sehingga tingginya koefisien determinasi karena trend bukan karena hubungan antara keduanya (Widarjono, 2005. Nelson dan Zivot, 2001)

Prosedur untuk menentukan apakah data stasioner atau tidak dengan cara membandingkan antara nilai statistik DF dengan nilai kritisnya. Jika nilai absolut statistik DF lebih besar dari nilai kritisnya maka, data yang diamati menunjukkan stasioner dan jika sebaliknya maka data tidak stasioner. Bila dalam uji akar unit tersebut menghasilkan kesimpulan bahwa data tidak stasioner, maka diperlukan langkah berikutnya yaitu uji derajat integrasi. (Gujarati, 1995. Insukindro, 1993).

Hasil pengujian pada Tabel 1. menunjukkan bahwa semua variabel ternyata stasioner pada first-different atau telah berintegrasi pada derajat satu, I(1). Dengan demikian dapat dilakukan langkah pengujian selanjutnya.

\section{Tabel 1. Hasil Pengujian Stasioneritas Data}

\begin{tabular}{ccc}
\hline Variabel & Level, I $(0)$ & 1 st difference, $\mathrm{I}(1)$ \\
\hline $\mathbf{C t}$ & $\mathbf{1 . 3 2 3 0 2 3}$ & $\mathbf{- 4 . 1 6 0 4 9 3}$ \\
$\mathbf{Y t}$ & $\mathbf{1 . 9 5 8 0 4 6}$ & $\mathbf{- 5 . 0 0 5 0 7 8}$ \\
$\mathbf{R}$ & $\mathbf{- 1 . 8 6 5 2 8 4}$ & $\mathbf{- 2 . 3 7 2 2 2 0}$ \\
\hline
\end{tabular}

Keterangan: *) Signifikan pada $\alpha$ 5\% dan $10 \%$. 


\section{Fungsi Konsumsi Rumah Tangga di Indonesia \\ Sangaji}

\section{Pendekatan Kointegrasi}

Pada prinsipnya pendekatan kointegrasi merupakan pengujian terhadap hubungan keseimbangan jangka panjang antara variabel ekonomi seperti yang dikehendaki oleh teori ekonomi. Pendekatan ini boleh pula dipandang sebagai ujian teori dan merupakan bagian penting dalam perumusan dan estimasi model empiris, khususnya model dinamik (Sriyana, 2003). Misalnya kita ingin menganalisis pengaruh pendapatan $(\mathrm{Yt})$ dan tingkat bunga $(\mathrm{r})$ terhadap tingkat konsumsi rumah tangga $(\mathrm{Ct})$, maka model yang kita punyai adalah sebagai berikut:

$$
C_{t}=\beta_{0}+\beta_{1} Y_{t}+\beta_{1} r e_{t}
$$

Dimana: $C_{t}=$ konsumsi rumah tangga

$$
\begin{aligned}
& \mathrm{Y}_{\mathrm{t}}=\text { pendapatan nasional } \\
& \mathrm{R}=\text { Tingkat bunga }
\end{aligned}
$$

Jika residual $e_{t}$ ternyata tidak mengandung akar unit atau data stasioner pada level atau $\mathrm{I}(0)$ maka kedua variabel $\mathrm{Ct}$, Yt dan rt adalah terkointegrasi yang berarti mempunyai hubungan jangka panjang. Secara umum dapat dikatakan bahwa jika data time series $\mathrm{Y}$ dan $\mathrm{X}$ tidak stasioner pada level tetapi menjadi stasioner pada diferensi (difference) yang sama yaitu $\mathrm{Y}$ adalah $\mathrm{I}(\mathrm{d})$ dan $\mathrm{X}$ adalah I(d) dimana d tingkat diferensi yang sama maka kedua data adalah terkointegrasi. Dengan kata lain uji kointegrasi hanya bisa dilakukan ketika data yang digunakan dalam penelitian berintegrasi pada derajat yang sama.

Tabel 2.Uji Akar-akar Unit variabel residual (Dickey-Fuller, DF)

\begin{tabular}{ccc}
\hline Variabel & Level, $\mathrm{I}(0)$ & Nilai kritis \\
& & MacKinnon \\
\hline $\mathrm{e}_{\mathrm{t}}$ & $\mathbf{- 2 . 8 8 3 5 5 6}$ & $\mathbf{- 2 . 6 5 3 4 0 1}$ \\
& & $\mathbf{- 1 . 9 5 3 8 5 8}$ \\
& & $\mathbf{- 1 . 6 0 9 5 7 1}$ \\
\hline
\end{tabular}

Keterangan: ") Signifikan pada $\alpha 1 \%, 5 \%$, dan $10 \%$.

Melalui pengujian stasioneritas, ternyata data semua variabel termasuk nilai residualnya berintegrasi pada level atau derajat yang sama, I(0). Ini berarti semua variabel yang diamati telah terkointegrasi pada data aslinya. Dengan demikian, dapat dikatakan bahwa terdapat hubungan keseimbangan jangka panjang diantara konsumsi rumah tangga dan pendapatan

\section{Stock Adjustment Atau Partial Adjustment Model (PAM)}

Rasionalisasi lain dari model Koyck adalah model penyesuaian parsial atau Partial adjustment model (PAM). Pertimbangan flexible accelarator model dari teori ekonomi mengasumsikan adanya keseimbangan optimal dalam jangka panjang (Awat, 1995). Misalkan asosiasi konsumsi yang diinginkan $\left(\mathrm{C}^{*}\right)$ dengan pendapatan $(\mathrm{Yt})$ dan suku bunga $(\mathrm{r})$ adalah

$$
\mathrm{C}_{\mathrm{t}}^{*}=\beta_{0}+\beta_{1} \mathrm{Y}_{\mathrm{t}}+\beta_{1} \mathrm{r}+\varepsilon_{\mathrm{t}}
$$

Karena tingkat konsumsi yang diinginkan tidak bisa diamati secara langsung, Nerlove mendalilkan hipotesis berikut ini, yang dikenal sebagai hipotesis penyesuaian parsial, atau penyesuaian stock:

$$
\mathrm{C}_{\mathrm{t}}-\mathrm{C}_{\mathrm{t}-1}=\delta\left(\mathrm{C}_{\mathrm{t}}^{*}-\mathrm{C}_{\mathrm{t}-1}\right)
$$

Di mana $0<\delta<1$ disebut koefisien peyesuaian; $\mathrm{C}_{\mathrm{t}}-\mathrm{C}_{\mathrm{t}-1}$ adalah perubahan aktual dari konsumsi; dan $\mathrm{C}_{\mathrm{t}}^{*}-\mathrm{C}_{\mathrm{t}-1}$ adalah perubahan konsumsi yang diinginkan.

Mekanisme penyesuaian (7) secara alternatif dapat ditulis sebagai berikut:

$$
\mathrm{Y}_{\mathrm{t}}=\delta \mathrm{Y}_{\mathrm{t}}^{*}+(1-\delta) \mathrm{Y}_{\mathrm{t}-1}
$$

Yang menunjukkan bahwa tingkat konsumsi yang diamati pada periode $t$ adalah rata-rata tertimbang dari tingkat konsumsi yang diinginkan pada saat itu dan tingkat konsumsi yang ada dalam periode waktu sebelumnya, dengan $\delta(1-\delta)$ sebagai bobotnya. Sekarang dengan mensubtitusikan (5) ke (7), maka persamaannya menjadi:

$$
\begin{aligned}
\mathrm{Y}_{\mathrm{t}} & =\delta\left(\beta_{0}+\beta_{1} \mathrm{Y}_{\mathrm{t}}+u_{\mathrm{t}}\right)+(1-\delta) \mathrm{Y}_{\mathrm{t}-1} \\
& =\delta \beta_{0}+\delta \beta_{1} \mathrm{Y}_{\mathrm{t}}+(1-\delta) \mathrm{Y}_{\mathrm{t}-1}+\delta u_{\mathrm{t}} \ldots \ldots \ldots \ldots \ldots \ldots
\end{aligned}
$$




\section{Journal of Indonesian Applied Economics Vol. 3 No. 2 Oktober 2009, 150-165}

Model ini disebut model penyesuaian parsial.

Berdasarkan hasil perhitungan, model regresi ini diperoleh $\pi=\delta=0.0024$. kombinasi model AE dan PAM ditunjukan pada lampiran. tingkat signifikansi model AE, PAM dan kombinasi AEPAM relatif baik.

Hasil pada tabel (lampiran) tersebut juga mengindikasikan bahwa perilaku konsumsi rumah tangga tidak mengikuti pada perubahan pendapatan dan suku bunga karena proses konsumsi mempengaruhi utilitas. Berdasarkan alasan waktu (lag), rumah tangga dapat belajar dari pengalaman mengkonsumsi periode sebelumnya karena perubahan konsumsi dan pendapatan tersebut belum tentu permanen atau sementara.

\section{Model Koreksi Kesalahan (ECM)}

Model koreksi kesalahan (Error Correction Model, ECM) telah diterapkan secara luas dalam analisis ekonometrika untuk data runtut waktu (time series), hal ini didukung oleh kemampuan ECM dalam meliputi lebih banyak variabel untuk menganalisis fenomena ekonomi jangka pendek serta jangka panjang (Kostov dan Linggard. Model ECM memiliki keunggulan khususnya dalam usaha mencari pemecahan terhadap persoalan variabel runtun waktu yang tidak stasioner (non stationarity), permasalahan regresi lancung (spurious regression) dan permasalahan korelasi lancung dalam analisis ekonometrika (Insukindro, 1999).

Secara statistik variabel koefisien ECT(-1) signifikan. Berarti, kesalahan keseimbangan dapat dikatakan mempengaruhi tingkat konsumsi rumah tangga. Hal ini dapat diartikan bahwa tingkat konsumsi rumah tangga menyesuaikan perubahan tingkat pendapatan dan suku bunga pada periode yang sama. Atau dengan kata lain, penyesuaian satu periode berikutnya untuk mengikuti periode jangka panjang tidak begitu berarti, sebab nilai koefisiennya hanya $9 \%$.

\section{Tabel 3. Hasil Pengujian Model Koreksi Kesalahan (ECM)}

\begin{tabular}{|c|c|c|c|c|}
\hline \multicolumn{5}{|c|}{ Depe ndent Variable: D(KONS) } \\
\hline \multicolumn{5}{|l|}{ Method: Least Squares } \\
\hline \multicolumn{5}{|c|}{ Date: $04 / 29 / 08$ Time: $20: 30$} \\
\hline \multicolumn{5}{|c|}{ Sample(adjusted): 2000:2 2006:3 } \\
\hline \multicolumn{5}{|c|}{ Included ob servations: 26 after adjusting endpo ints } \\
\hline Variable & Coefficient & Std. Error & t-Statistic & Prob. \\
\hline D(INCOME) & 0.099189 & 0.082531 & 1.201843 & 0.2422 \\
\hline D(BUNGA) & 4064.043 & 1380.905 & 2.943029 & 0.0075 \\
\hline ECT $(1)$ & 0.221043 & 0.100846 & 2.191882 & 0.0393 \\
\hline $\mathrm{C}$ & 10311.55 & 2228.835 & 4.626428 & 0.0001 \\
\hline R-squa red & 0.367772 & Mean depend ent var & & 12188.83 \\
\hline Adjusted R-square d & 0.281559 & S.D. dependent var & & 9455.272 \\
\hline S.E. of regression & 8014.375 & Akaike info criterion & & 20.95650 \\
\hline Sum squared resid & $1.41 \mathrm{E}+09$ & Schwarz criterion & & 21.15005 \\
\hline Log likelihood & -268.4345 & F-statistic & & 4.265854 \\
\hline Durbin-Watson stat & 3.023355 & Prob(F-statistic) & & 0.016156 \\
\hline
\end{tabular}

Output di atas juga memberikan informasi bahwa perubahan jangka pendek pada variabel pendapatan dan suku bunga mempunyai dampak positif pada perubahan jangka pendek tingkat konsumsi rumah tangga. Ini sekaligus menunjukkan bahwa jika koefisien $\alpha_{3}>0$, maka koefisien semua variabel independen $<0$.

\section{Pengujian Asumsi Klasik}

\section{Pengujian Autokorelasi (Breush-Godfrey Test)}

Uji ini mengasumsikan bahwa faktor pengganggu $\mathrm{u}_{\mathrm{t}}$ adalah diturunkan mengikuti path-order autoregressive scheme di mana persamaan tersebut dibentuk dari model persamaan regresi, sehingga diperoleh hasil sebagai berikut. 
Tabel 4. Hasil Pengujian Autokorelasi

\begin{tabular}{lccc}
\hline \multicolumn{3}{l}{ Breusch-Godfrey } & Serial Correlation LM Test: \\
\hline F-statistic & 2.000042 & Probability & 0.154622 \\
& & & \\
Obs*R-squared & 5.727361 & Probability & 0.125655 \\
\hline
\end{tabular}

Keterangan: Tidak Signifikan pada $\alpha$ 5\%

Hasil tersebut menunjukkan bahwa nilai F statistik tidak siginifikan pada $\alpha 5 \%$ maupun $1 \%$, sehingga dapat disimpulkan dalam model empiris yang digunakan tidak ditemukan adanya gejala autokorelasi.

\section{Pengujian Heteroskedastisitas (White Heteroskedasticity Test)}

Uji ini dilakukan dengan meregresi residual kuadrat $\left(\mathrm{vt}^{2}\right)$ dengan variabel-variabel bebas, variabel bebas kuadrat dan perkalian variabel bebas. Indikasi ada atau tidaknya heteroskedastisitas dengan menghitung nilai $X^{2}$ dimana $\mathrm{X}^{2}=\mathrm{n}^{*} \mathrm{R}^{2}$. pengujiannya adalah jika dari hasil perhitungan ternyata $\mathrm{X}^{2}$-hitung $<\mathrm{X}^{2}$-tabel. Berarti hipotesis alternatif adanya heteroskedastisitas ditolak. Adapun hasil uji White menunjukkan bahwa persamaan konsumsi rumah tangga tidak mengandung heterokedastisitas

\section{Tabel 5. Hasil Pengujian Heteroskedastisitas}

\begin{tabular}{llll}
\hline White Heteroskedasticity Test: & & \\
\hline F-statistic & 0.659866 & Probability & 0.626101 \\
Obs ${ }^{*}$ R-squared & 2.882472 & Probability & 0.577682 \\
\hline
\end{tabular}

Keterangan: Tidak Signifikan pada $\alpha$ 5\%

\section{Pengujian Multikolinieritas (Partial Correlation)}

Jika deteksi masalah multikolinieritas hanya dengan melihat nilai $\mathrm{R}^{2}$ dan uji signifikansi melalui uji $\mathrm{t}$ bisa saja memberikan hasil bahwa masalah multikolinieritas tidak terdapat dalam model regresi, dikarenakan semua koefisien secara statistik adalah signifikan dengan koefisien determinasi $\left(\mathrm{R}^{2}\right)$ yang cukup rendah. Bagaimana dengan deteksi koefisien korelasi antar variabel indepdenden?

\section{Tabel 6. Hasil Pengujian Multikolinieritas}

\begin{tabular}{ccc}
\hline & INCOME & BUNGA \\
\hline INCOME & 1 & -0.344338 \\
BUNGA & -0.344338 & 1 \\
\hline
\end{tabular}

Keterangan: Tidak Signifikan pada $\alpha 5 \%$

Nilai koefisien korelasi dapat dilihat bahwa korelasi antara INCOME dengan BUNGA sebesar 0,344338. Melihat rendahnya nilai koefisien korelasi maka diduga tidak terdapat masalah multikolinieritas.

\section{Pengujian Linieritas (Ramsey Reset test)}

Uji ini merupakan uji tentang linieritas model yang diamati. Uji ini perlu mengingat bahwa kesalahan spesifikasi model dapat berakibat inefisiensi penaksir. Pengujian dapat dilakukan dengan statistik F mengingat bahwa prosedur ini sama dengan pengujian signifikansi variabel secara bersama-sama di dalam suatu model (joint significance of explanatory variables). 
Journal of Indonesian Applied Economics

Vol. 3 No. 2 Oktober 2009, 150-165

Tabel 7. Hasil Pengujian Linieritas

Ramsey RESET Test:

\begin{tabular}{llll}
\hline F-statistic & 2.551343 & Probability & 0.125140 \\
Log likelihood ratio & 2.981171 & Probability & 0.084238 \\
\hline
\end{tabular}

Keterangan: Tidak Signifikan pada $\alpha$ 5\%

Hasil pengujian pada tabel 7, menunjukkan bahwa model yang digunakan ternyata model linier. Hal ini ditunjukkan oleh nilai F-statistik yang tidak signifikan atau kecil dari nilai $\mathrm{F}$ tabel pada tingkat keyakinan $99 \%$.

\section{HASIL DAN PEMBAHASAN}

\section{Pengaruh Tingkat Pendapatan terhadap Tingkat Konsumsi Rumah Tangga}

Teori konsumsi Keynes menyatakan bahwa konsumsi sekarang (current consumption) tergantung pada pendapatan sekarang (current income). Menurut Keynes, ada batas minimal yang tidak tergantung tingkat pendapatan. Artinya, tingkat konsumsi tersebut harus dipenuhi, walaupun tingkat pendapatan sama dengan nol. Itulah yang disebut dengan konsumsi otonomus (autonomous consumption). Jika pendapatan disposable meningkat, maka konsumsi juga akan meningkat. Hanya saja peningkatan konsumsi tersebut tidak sebesar peningkatan pendapatan disposable (Mankiw, 2003).

Berdasarkan hasil penelitian menunjukkan bahwa pendapatan berpengaruh signifikan terhadap tingkat konsumsi rumah tangga di Indonesia. Hasilnya juga menunjukkan bahwa terdapat hubungan positif diantara pendapatan rumah tangga dengan pola konsumsi. Artinya, jika semakin tinggi penghasilan rumah tangga maka akan terjadi peningkatan dalam tingkat konsumsi rumah tangga. Hasil ini sejalan dengan penelitian yang telah dilakukan terdahulu seperti studi yang dikemukakan Kimin (2002) dimana ditemukan bahwa peningkatan pendapatan diikuti oleh meningkatnya konsumsi dengan mengikuti pola konsumsi jangka pendek. Hasil ini juga menguatkan temuan dari Hani (2006) yang menyatakan bahwa setiap terjadi kenaikan pendapatan akan menaikan tingkat konsumsi rumah tangga. Dan konsumsi rumah tangga akan sangat dipengaruhi oleh perilaku konsumsi periode sebelumnya, biasanya karena alasan psikologis. Dengan alasan ini maka orang tidak langsung merubah kebiasaan konsumsinya dengan segera walaupun terjadi penurunan harga ataupun terjadi kenaikan pendapatan. Dan penelitian Hani juga sejalan dengan penelitian yang telah dilakukan oleh Ratnawati dan Rizki (2004) dari hasil kajian tentang pola konsumsi dan pendapatan menggambarkan adanya kecenderungan konsumsi rumah tangga dipengaruhi oleh variasi pendapatan nasional dan konsumsi periode sebelumnya. Di mana seseorang akan mempertahankan tingkat konsumsi yang tetap yang dapat dipertahankan oleh seseorang dengan tingkat pendapatan saat ini dan pendapatan yang akan datang.

\section{Pengaruh Tingkat Suku Bunga terhadap Tingkat Konsumsi Rumah Tangga}

Bunga adalah imbalan bagi penabung karena menunda konsumsi. Bunga juga dapat berarti sejumlah imbalan yang dibayar peminjam atas daya beli saat ini. Pada saat kita membuat grafik fungsi konsumsi tertentu, kita harus juga mengasumsikan tingkat bunga tertentu. Jika tingkat bunga naik dan hal lain diasumsikan konstan, penabung atau pemberi pinjaman diberi imbalan lebih banyak dan peminjam dipungut lebih banyak. Pada tingkat bunga yang lebih tinggi, rumah tangga akan menabung lebih banyak, meminjam lebih sedikit, dan berbelanja lebih sedikit. Tabungan yang lebih tinggi pada semua tingkat pendapatan sama saja dengan konsumsi yang lebih sedikit.

Dari hasil kajian penelitian menunjukan bahwa tingkat bunga berpengaruh signifikan terhadap tingkat konsumsi rumah tangga di Indonesia. Hasilnya juga menunjukkan bahwa terdapat hubungan positif diantara tingkat bunga dengan pola konsumsi. Dengan demikian, naiknya suku bunga akan 


\section{Fungsi Konsumsi Rumah Tangga di Indonesia \\ Sangaji}

mengurangi pengeluaran konsumsi rumah tangga. Kajian ini tidak berbeda dengan penelitian yang telah dilakukan oleh Raut dan Virmani (1990). Dari hasil kajian penelitian mereka menggambarkan tingkat bunga riil mempunyai efek positif terhadap konsumsi, maka tingkat bunga nominal dan tingkat inflasi keduanya mempunyai efek negatif terhadap tingkat bunga nominal. Hal ini dapat dipahami, bahwa efek inflasi tersebut adalah dapat meningkatkan ketidakpastian penghasilan mendatang dan dengan demikian meningkatkan permintaan terhadap tabungan, serta inflasi mempunyai efek negatif terhadap kekayaan keuangan riil, olehnya itu akan membutuhkan pengurangan konsumsi untuk mempertahankan persediaan tabungan riil. Secara sederhana dapat dikatakan bahwa orang akan lebih cenderung menabung jika inflasi lebih tinggi, disebabkan terjadi penurunan konsumsi riil dan akan ada kenaikan suku bunga.

\section{E. KESIMPULAN DAN REKOMENDASI}

\section{Kesimpulan Penelitian}

Teori konsumsi Keynes menjelaskan bahwa tingkat konsumsi sekarang (current consumption) di pengaruhi oleh pendapatan sekarang (current income) dan tingkat suku bunga. Artinya bahwa seseorang atau rumah tangga akan menambah konsumsinya jika terjadi kenaikan dalam pendapatan sekarang. Disamping itu, suku bunga yang tinggi akan menarik orang untuk menabung, pada akhirnya mengurangi tingkat konsumsinya. Dengan demikian terdapat hubungan negatif atau berlawanan antara tingkat bunga dengan konsumsi rumah tangga.

Kondisi diatas sejalan dengan hasil penelitian bahwa terdapat hubungan positif antara tingkat konsumsi dengan tingkat pendapatan. Dimana rumah tangga akan senantiasa menaikkan konsumsinya jika terjadi kenaikan dalam tingkat pendapatan. Sementara tingkat bunga berpengaruh negatif terhadap tingkat konsumsi rumah tangga. Hal ini mengandung makna bahwa rumah tangga akan mengurangi konsumsinya dan memilih untuk menabung disaat terjadi kenaikan suku bunga.

Mendasarkan kepada kesimpulan tersebut peneliti merekomendasikan pertama. Tingginya tingkat bunga akan menyebabkan rumah tangga akan memilih untuk menabung, dan mengurangi pengeluarannya untuk konsumsi. Hal ini akan berdampak pada tingginya tabungan, tetapi mengganggu iklim investasi yang disebabkan menurunnya permintaan kredit oleh para investor, yang pada gilirannya menurunkan pertumbuhan ekonomi. Olehnya itu kebijakan pemerintah dalam menaikkan suku bunga agar berada pada level yang optimal agar tidak menghambat aktivitas perekonomian secara makro. Dan, kedua. Karena tingkat konsumsi sangat tergantung pada tingkat pendapatan, maka kiranya perlu adanya suatu kebijakan yang dapat meningkatkan pendapatan rumaha tangga, yakni dengan usaha menciptakan lapangan pekerjaan bagi masyarakat. Dengan demikian, pendapatan yang dimiliki rumah tangga bukan hanya habis digunakan untuk konsumsi barang makanan saja, tetapi juga untuk konsumsi barang mewah. Selain itu, rumah tangga bisa menyisihkan sisa pendapatan untuk tabungan.

\section{DAFTAR PUSTAKA}

Burhan, Umar. 2005. Perilaku Rumah Tangga Muslim dalam Menabung, Berinvestasi, dan Menyusun Portofolio Kekayaan dan Implikasinya Terhadap Perkembangan Bank Syariah. Disertasi Program Pascasarjana Universitas Brawijaya, Malang.

BI. 2007. Suku Bunga Konsumsi. Analisis Ekonomi. Jurnal Ekonomi dan Bisnis Research. 2007.

BPS Indonesia,www.gogle.com. Data Konsumsi, Pendapatan dan Tingkat Bunga.

Dornbusch, Rudiger \& Fisher, Stanley. 1987. Macroeconomics. Sixth edition. McGraw - Hill, Inc, New York. 


\section{Journal of Indonesian Applied Economics \\ Vol. 3 No. 2 Oktober 2009, 150-165}

Gujarati, Damodar, 1995., Basic Econometrics, Fourth Edition. New York:McGraw-Hill.

Herlambang, Tedy., et.al. 2001. Ekonomi Makro; Teori, Analisis, dan Kebijakan.

Hani, Umi, 2006. Sustainabilitas Fiskal Indonesia Yang Mempengaruhi Analisis Model. Jurnal keuangan Publik. Vo.4, No.2, September, 2006.

Penerbit PT Gramedia Pustaka Utama, Jakarta.

Ismail, Munawar.,et.al., 2005. Uji Hipotesis “Jalan Acak” dalam Fungsi Konsumsi di Indonesia. Jurnal Ekonomi dan Bisnis Indonesia, Vol. 20, No.2, April 2005. FE-UGM, Yogyakarta.

Insukindro, 1993., Ekonomi Uang dan Bank; Teori dan Pengalaman di Indonesia, Edisi Pertama. Penerbit BPFE-UGM, Yogyakarta.

, 1999., Pemilihan Model Empirik Dengan Pendekatan Koreksi Kesalahan, Jurnal Ekonomi dan Bisnis Indonesia, Vol. 14: 1-8, BPFE_UGM, Yoyakarta.

Kimin, Basir. 2002. Pola Konsumsi Petani Karet Sawah Ditinjau dari Hipotesis Pendapatan Relatif "Studi KasusTiga Desa di Kec. Sirahpulaupadang”. Jurnal Ekonomi dan Bisnis Indonesia. Vol. 17, No. 3, Juli 2002. FE-UGM, Yogyakarta.

Krisnawati, Enni., et.al., 2004. Analisis Pola Konsumsi Rumah Tangga Nelayan dalam Perspektif Ekonomi dan Sosial (Studi Kasus pada Desa Bandaran Kec. Tlanakan, Kab. Pamekasan). Jurnal TEMA Vol. 5, No.1, Maret 2004. FE-Unibraw Malang.

Mankiw, Gregory N, 2003. Makroeconomics $5^{\text {th }}$ Edition. New York and Basingstoke by Worth Publishers.

Metwally, M.M, 1995., Teori dan Model Ekonomi Islam. PT. Bangkit Daya Insana, Edisi Pertama, Jakarta.

Nachrowi, Djalal Nachrowi \& Usman, Hardius, 2006. Ekonometrika untuk Analisis Ekonomi dan Keuangan; Pendekatan Populer dan Praktis. Lembaga Penerbit FE-UI, Jakarta.

Nelson, C. R, J. Piger, and E. Zivot (2001) Markov Regime Switching and Unit- Root Tests, Journal of Business and Economic Statistics.

Pracoyo, Tri Kunawangsih \& Pracoyo, Anto. 2005. Aspek Dasar Ekonomi Makro Di Indonesia. Penerbit PT Gramedia Widiasarana Indonesia, Jakarta.

Ratnawati, Nirdukita \& Rizki, Rulli., 2004. “Analisis Pengaruh Variabel Indikator Makro Ekonomi Terhadap Ekonomi Makro Indonesia: Pendekatan Pasar Barang dan Pasar Uang, Periode 1990.1 - 2003.4. Jurnal Media Ekonomi, Vol. 10, No.3, Desember. LPFE, Universitas Trisakti Jakarta.

Raut, Lakshmi. K \& Virmani, Arvind. 1990. "Determinants of Consumption and Savings Behavior in Developing Countries”, The World Bank Economic Review, Vol. 3, No.3.

Romer, David. 1996. Advanced Macroeconomics, Chapter 7, The McGraw-Hill Companies, Inc.

Samuelson, Paul. A. \& Nordhaus, William. D., Macroeconomics, $17^{\text {th }}$ edition. By McGraw-Hill Companies, Inc. all rights reserved New York. Diterjemahkan oleh Gretta., et.al. Diterbitkan oleh P.T. Media Global Edukasi, Jakarta.

Sriyana, Jaka. 2003., Evolusi Ekonometrik Dinamik dalam Analisis Data Time Series., Jurnal Ekonomi \& Studi Pembangunan, Vol. 4. No. 2. FE Universitas Muhammadiyah, Yogyakarta. 


\section{Fungsi Konsumsi Rumah Tangga di Indonesia}

Sukirno, Sadono, 2000. Makroekonomi Modern. Perkembangan Pemikiran Dari Klasik Hingga Keynesian Baru. PT RajaGrafindo Persada, Jakarta.

Widarjono, Agus. 2005., Ekonometrika: Teori dan Aplikasi untuk Ekonomi dan Bisnis, Edisi Pertama. Penerbit Ekonisia Fakultas Ekonomi UII, Yogyakarta. 


\section{Journal of Indonesian Applied Economics}

Vol. 3 No. 2 Oktober 2009, 150-165

\section{LAMPIRAN}

\section{Hasil Pengujian Regresi Linier Berganda Fungsi Konsumsi}

\begin{tabular}{|c|c|c|c|c|}
\hline \multicolumn{5}{|c|}{ Dependent Variable: KONS } \\
\hline \multicolumn{5}{|c|}{ Method: Least Squares } \\
\hline \multicolumn{5}{|c|}{ Date: $04 / 30 / 08$ Time: $20: 00$} \\
\hline \multicolumn{5}{|c|}{ Sample: 2000:1 2006:4 } \\
\hline \multicolumn{5}{|c|}{ Included ob servations: 28} \\
\hline Variable & Coefficient & Std. Error & $\mathrm{t}$-Statistic & Prob. \\
\hline INCOME & 0.692604 & 0.024264 & 28.54481 & 0.0000 \\
\hline BUNGA & -2222.816 & 1076.794 & -2.064290 & 0.0495 \\
\hline $\mathrm{C}$ & 41861.79 & 19368.29 & 2.161357 & 0.0404 \\
\hline $\mathrm{R}$-squared & 0.975007 & Mean deper & var & 355118.6 \\
\hline Adjusted R-squared & 0.973008 & S.D. depenc & & 102226.0 \\
\hline S.E. of regression & 16795.04 & Akaike info & erion & 22.39651 \\
\hline Sum squared resid & $7.05 \mathrm{E}+09$ & Schwarz cri & & 22.53925 \\
\hline Log likelihood & -310.5512 & F-statistic & & 487.6431 \\
\hline Durbin-Watson stat & 0.972106 & Prob(F-stati & & 0.000000 \\
\hline
\end{tabular}

Fungsi konsumsi dengan Rasionalisasi Model Koyck: Model AE dan PAM

\begin{tabular}{|c|c|c|c|c|}
\hline \multicolumn{5}{|c|}{ Dependent Variable: KONS } \\
\hline \multicolumn{5}{|c|}{ Method: Least Squares } \\
\hline \multicolumn{5}{|c|}{ Date: $04 / 30 / 08$ Time: $14: 28$} \\
\hline \multicolumn{5}{|c|}{ Sample(adjusted): 2000:1 2006:3 } \\
\hline \multicolumn{5}{|c|}{ Included observations: 27 after ad justing endpoints } \\
\hline Variable & Coefficient & Std. Error & t-Statistic & Prob. \\
\hline INCOME & -0.043495 & 0.127117 & -0.342165 & 0.7353 \\
\hline BUNGA & -349.3528 & 778.6916 & -0.448641 & 0.6579 \\
\hline KONS(1) & 0.997571 & 0.170089 & 5.864991 & 0.0000 \\
\hline $\mathrm{C}$ & 11683.14 & 14152.95 & 0.825492 & 0.4176 \\
\hline R-squared & 0.987934 & \multicolumn{2}{|c|}{ Mean dep endent var } & 347123.1 \\
\hline Adjusted R-squared & 0.986360 & \multirow{2}{*}{\multicolumn{2}{|c|}{ S.D. dependent var }} & 94832.90 \\
\hline S.E. of regression & 11075.42 & & & 21.59880 \\
\hline Sum squared resid & $2.82 \mathrm{E}+09$ & \multicolumn{2}{|c|}{ Schwarz criterion } & 21.79077 \\
\hline Log likelihood & -287.5838 & \multicolumn{2}{|l|}{ F-statistic } & 627.7375 \\
\hline Durbin-Watson stat & 2.110539 & \multicolumn{2}{|c|}{ Prob(F-statistic) } & 0.000000 \\
\hline
\end{tabular}




\section{Fungsi Konsumsi Rumah Tangga di Indonesia \\ Sangaji}

\section{Perbaikan Model AE, PAM dan Kombinasi AE dan PAM}

\begin{tabular}{|c|c|c|c|c|}
\hline \multicolumn{5}{|c|}{ Dependent Variable: D(KONS) } \\
\hline \multicolumn{5}{|c|}{ Method: Least Squares } \\
\hline \multicolumn{5}{|c|}{ Date: $04 / 29 / 08$ Time: $20: 25$} \\
\hline \multicolumn{5}{|c|}{ Sample(adjusted): 2000:3 2006:4 } \\
\hline \multicolumn{5}{|c|}{ Included ob servations: 26 after ad justing endpoints } \\
\hline \multicolumn{5}{|c|}{ Convergence achieved after 52 iterations } \\
\hline \multicolumn{5}{|l|}{ Backcast: $2000: 2$} \\
\hline Variable & Coefficient & Std. Error & t-Statistic & Prob. \\
\hline D(INCOME) & 0.204854 & 0.066352 & 3.087406 & 0.0056 \\
\hline $\mathrm{D}(\mathrm{BUNGA})$ & 1217.954 & 1180.785 & 1.031479 & 0.3141 \\
\hline $\mathrm{D}(\mathrm{KONS}(-1))$ & 0.426888 & 0.218862 & 1.950493 & 0.0646 \\
\hline $\mathrm{C}$ & 4253.969 & 2879.148 & 1.477510 & 0.1544 \\
\hline $\operatorname{MA}(1)$ & -0.907636 & 0.097833 & -9.277424 & 0.0000 \\
\hline R-squared & 0.464031 & \multicolumn{2}{|c|}{ Mean dependent var } & 13854.35 \\
\hline Adjusted R-squared & 0.361941 & \multicolumn{2}{|c|}{ S.D. dependent var } & 12011.42 \\
\hline S.E. of regression & 9594.551 & \multicolumn{2}{|c|}{ Akaike info criterion } & 21.34682 \\
\hline Sum squared resid & $1.93 \mathrm{E}+09$ & \multicolumn{2}{|c|}{ Schwarz criterion } & 21.58876 \\
\hline Log likelihood & -272.5087 & \multicolumn{2}{|l|}{ F-statistic } & 4.545337 \\
\hline Durbin-Watson stat & 2.046032 & \multicolumn{2}{|c|}{ Prob(F-statistic) } & 0.008410 \\
\hline Inverted MA Roots & .91 & & & \\
\hline
\end{tabular}

\section{Model Koreksi Kesalahan (ECM)}

\begin{tabular}{|c|c|c|c|c|}
\hline \multicolumn{5}{|c|}{ Dependent Variable: D(KONS) } \\
\hline \multicolumn{5}{|c|}{ Method: Least Squares } \\
\hline \multicolumn{5}{|c|}{ Date: $04 / 29 / 08$ Time: $20: 30$} \\
\hline \multicolumn{5}{|c|}{ Sample(adjusted): $2000: 22006: 3$} \\
\hline \multicolumn{5}{|c|}{ Included ob servations: 26 after ad justing endpoints } \\
\hline Variable & Coefficient & Std. Error & t-Statistic & Prob. \\
\hline D(INCOME) & 0.099189 & 0.082531 & 1.201843 & 0.2422 \\
\hline D(BUNGA) & 4064.043 & 1380.905 & 2.943029 & 0.0075 \\
\hline $\mathrm{ECT}(1)$ & 0.221043 & 0.100846 & 2.191882 & 0.0393 \\
\hline $\mathrm{C}$ & 10311.55 & 2228.835 & 4.626428 & 0.0001 \\
\hline R-squared & 0.367772 & \multicolumn{2}{|c|}{ Mean dependent var } & 12188.83 \\
\hline Adjusted R-squared & 0.281559 & \multirow{2}{*}{\multicolumn{2}{|c|}{$\begin{array}{l}\text { S.D. dependent var } \\
\text { Akaike info criterion }\end{array}$}} & 9455.272 \\
\hline S.E. of regression & 8014.375 & & & 20.95650 \\
\hline Sum squared resid & $1.41 \mathrm{E}+09$ & \multicolumn{2}{|c|}{ Schwarz criterion } & 21.15005 \\
\hline Log likelihood & -268.4345 & \multicolumn{2}{|c|}{ F-statistic } & 4.265854 \\
\hline Durbin-Watson stat & 3.023355 & \multicolumn{2}{|c|}{ Prob(F-statistic) } & 0.016156 \\
\hline
\end{tabular}

